Support for Public Research Spin-offs by the Parent Organizations and the Speed of Commercialization

Viktor Slavtchev

Devrim Göktepe-Hultén

October 2015

No. 16 
Authors: Viktor Slavtchev (corresponding author) Halle Institute for Economic Research (IWH) - Member of the Leibniz Association Department of Structural Change and Productivity E-mail: viktor.slavtchev@iwh-halle.de Phone: +493457753 743

Devrim Göktepe-Hultén

Lund University

School of Economics and Management E-mail: devrim.goktepe-hulten@fek.lu.se Phone: +46462223359

The responsibility for discussion papers lies solely with the individual authors. The views expressed herein do not necessarily represent those of the IWH. The papers represent preliminary work and are circulated to encourage discussion with the authors. Citation of the discussion papers should account for their provisional character; a revised version may be available directly from the authors.

Comments and suggestions on the methods and results presented are welcome.

IWH Discussion Papers are indexed in RePEc-EconPapers and in ECONIS.

Editor:

Halle Institute for Economic Research (IWH) - Member of the Leibniz Association

Address: $\quad$ Kleine Maerkerstrasse 8, D-06108 Halle (Saale), Germany

Postal Address: P.O. Box 1103 61, D-06017 Halle (Saale), Germany

Phone: $\quad+49345775360$

Fax: $\quad+493457753820$

Internet: $\quad$ www.iwh-halle.de

ISSN $1860-5303$ (Print)

ISSN 2194-2188 (Online) 


\title{
Support for Public Research Spin-offs by the Parent Organizations and the Speed of Commercialization
}

\begin{abstract}
We empirically analyze whether support by the parent organization in the early (nascent and seed) stage speeds up the process of commercialization and helps spin-offs from public research organizations generate first revenues sooner. To identify the impact of support by the parent organization, we apply multivariate regression techniques as well as an instrumental variable approach. Our results show that support in the early stage by the parent organization can speed up commercialization. Moreover, we identify two distinct channels - the help in developing a business plan and in acquiring external capital - through which support by the parent organization can enable spin-offs to generate first revenues sooner.
\end{abstract}

Keywords: academic entrepreneurship, support, TTO, commercialization, time to market

JEL Classification: L26, M13, O31, O32, O33 



\section{Introduction}

Spin-offs from universities and public research organizations (PRO) (hereafter public research spin-offs) are one key mechanism to commercialize knowledge and technologies generated and invented at these organizations and, thereby, to stimulate economic growth and development (Shane 2004; Wright et al. 2007; Astebro and Bazzazian 2011). Accordingly, public policy deliberately encourages universities and public research organizations to develop and implement structures and mechanisms (i) to promote entrepreneurial culture and spirit among scientists and to increase their awareness of entrepreneurship as a career opportunity, and (ii) to actively support scientists interested in entrepreneurship in order to speed up the process and increase the chances of a successful commercialization (Mowery et al. 2004; Link and Siegel 2005; Muster and Wright 2010; Grimaldi et al. 2011; O'Kane et al. 2015; Etzkowitz 2004).

To this date, an abundant literature on entrepreneurship from universities and PROs emerged (Vohora et al. 2004; Shane 2004; Lerner 2005; Wright et al. 2007; Rothaermel et al. 2007; Mustar et al. 2008; Bozeman et al. 2015). However, most prior research is primarily interested in the question of how to stimulate the entrepreneurship rates at PROs and focuses mainly on the determinants of the decision of scientists to become entrepreneurs. In particular, mostly the individual characteristics of the scientists as well as the characteristics of their parent organizations which are associated with higher average entrepreneurial propensity at individual or organizational level have been investigated. For instance, it has been found that the entrepreneurial propensity is higher for scientists who conduct intensive R\&D; have contacts to industry and finance; have work experience in the private sector, in particular managerial and entrepreneurial experience; etc. (Lockett and Wright 2005; Krabel and Mueller 2009; Fini et al. 2009). Similarly, the number of spin-offs at PROs is found positively associated with the R\&D expenditures at these organizations; the availability and the endowment of technology transfer offices (i.e. the amount of resources and number of personnel) as well as the competences and qualification of the staff; the availability of venture funds; the expenditures on intellectual property rights (e.g. patents and trademarks); the business development capabilities of the PROs; the embeddedness of universities and PROs in networks; etc. (Phan and Siegel 2006; Powers and McDougall 2005; Clarysse et al. 2011; Hayter and Link 2015; Boeker 1989; Di Gregorio and Shane 2003; Lockett and Wright 2005; Lockett et al. 2005; Moray and Clarysse 2005; O'Kane et al. 2015; O’Shea et al. 2005; Siegel et al. 2007; Brennan et al. 2005; Brennan and McGowan 2006; Holley and Watson 2011). 
From these results has been deduced—implicitly or explicitly—about appropriate measures to increase the incidence of entrepreneurship at PROs.

Comparably few studies, however, seek to understand (i) whether and (ii) through which channels and mechanisms support measures for spin-offs at the PROs impact on the development and performance of the newly created companies rather than to look at the individual and organizational determinants of scientists' decisions to engage in entrepreneurship (cf. Phan and Siegel 2006 for excellent overview). Further research along these lines is required, particularly because public research spin-offs do not necessarily outperform similar non-academic startups (Astebro and Bazzazian 2011; Astebro et al. 2012; Lindholm Dahlstrand 1997; Ensley and Hmieleski 2005; Shane 2008; Zhang 2009; Koster 2006; Stephan 2014).

In this paper, we econometrically analyze whether support by the parent organizations in the nascent or seed phase can speed up the process of commercialization and can help public research spin-offs quickly generate first revenues (speed up the time to the market). Moreover, we investigate two distinct channels - the development of a business plan and the acquisition of external capital - through which support by the parent organization can speed up commercialization. The ability to quickly enter the market with a marketable product, to generate revenues and thereby to break even is positively associated with subsequent survival, development and performance (McEvily et al. 2004; Meyer 1993; Rosenthal 1992;

Wheelwright and Clark 1996; Kessler and Chakrabarti 1996; McGrath 1999). In fact, firms that succeed in speeding products faster to the market can obtain first-mover advantage, higher profitability and market shares (Droege et al. 2005; Takeuchi and Nonaka 1986; Eisenhardt and Martin 2000). In general, initial conditions have long-term performance implications (Cooper et al. 1994; Dahlqvist et al. 2000). We focus on the early phases of the process of venture creation because especially in these early stages of development, academic spin-offs are particularly dependent on support by their parent organization (Grimaldi et al. 2011). Academic research is predominantly basic in nature and directed towards extending the frontier of scientific knowledge rather than towards a commercial end. Accordingly, the business ideas of public research spin-offs are novel but typically embryonic and a substantial amount of time and resources (i.e. capital) is required for further research and development in order to transform them into commercial products. At the same time scientists mostly lack entrepreneurial and managerial competences, business contacts and networks, knowledge about customers' needs and preferences, legal issues, etc. Not surprisingly, private financiers, 
including venture capital companies, are generally reluctant in the early stages of the development of public research startups.

We investigate whether support by the parent organization can speed up the process of commercialization at the example of public research spin-offs from the Max Planck Society (MPG) in Germany, which maintain 78 institutes in Germany and is regarded as one of worldwide most distinguished public research organizations. Specifically, in order to get as many entrepreneurs as possible, we apply the nascent entrepreneurship concept (Reynolds et al. 2004a, b; Astebro and Bazzazian 2011), and focus on the time from starting any activity towards establishing an own firm to the date they expect to generate first revenues as a proxy for the time to market (or the speed of commercialization). Though focused on basic research, the MPG has an institutionalized technology transfer office (TTO)—Max Planck Innovation (MPI) - , whose mission is to promote and support the commercialization of research ideas generated at the MPG (i) through licensing, and (ii) by supporting spin-offs by scientists from the society in the early conceptual and seed phases (Max Planck Innovation 2015). Accordingly, similar to other universities and PROs around the world ${ }^{1}$, MPI offers a wide range of assistance and support measures.

The results of the econometric analysis suggest that support in the early stage by the parent organization can facilitate the process of commercialization and that supported spin-offs expect to generate first revenues earlier than not-supported counterparts. Specifically, we apply multivariate regression techniques to assess the impact of support by the parent organization in the early stage on the expected time to first revenues conditional on a number of control variables (i.e. characteristics of the founders and the new ventures, as well as environmental characteristics that might influence their expectations). Moreover, to avoid potentially biased estimates-for instance, if the likelihood that spin-offs are among the supported is related (directly or through unaccounted factors) to their ability to quickly generate first revenues_-, we additionally apply instrumental variable (IV) techniques. In the IV approach, we make use of the fact that support for the spin-offs requires close and frequent interactions between founder and the supporting organization, so that scientists located closer to Max Planck Innovation are c.p. more likely to make use of it, regardless their type and abilities. Thus, as an instrument we use the travel time between the working place of a scientist (i.e. the institute) and the Max Planck Innovation in Munich, which is arguably not

\footnotetext{
${ }^{1}$ For examples of support measures for entrepreneurs at universities around the world see-among many others-Shane (2004), Wright et al. (2007), Astebro and Bazzazian (2011), O'Shea et al. (2004), Lockett and Wright (2005), Phan and Siegel (2006), O'Kane et al. (2015), Hayter and Link (2015), Wright et al. (2006), Moray and Clarysse (2005), Walter et al. (2006).
} 
related to the characteristics of the founder, the venture or the local environment which might also influence the speed of commercialization. Moreover, we show that developing a business plan and acquiring external capital are two distinct channels through which the impact of support by the public organization on the speed of commercialization unfolds.

Our study complements the existing literature on entrepreneurship at PROs by adding to the understanding of whether and through which channels do support measures at PROs help scientists in their entrepreneurial ventures. Moray and Clarysse (2005) provide - at the example of 23 spin-offs from the Inter University Micro Electronics Centre (IMEC) in Belgium, one of worldwide most excellent research centers - anecdotic evidence that support from the parent organization can improve the capitalization, increase the initial size, and can help enter the market with a prototype that already works in a real life environment. Markman et al. (2005) use phone interview data from 91 TTOs at US universities to analyze how selected characteristics of the TTOs influence the time from the disclosure of university-made inventions to their licensing to private companies. However, none of these studies analyzes whether support by the parent organization helps public research spin-offs generate first revenues quicker. By relating support by the parent organization to the speed of commercialization and how long it takes for the spin-offs to generate first revenues, we add to the understanding of whether and how support by the parent organization can impact on the development of the ventures. Moreover, we contribute also to the literature that seeks to evaluate the effectiveness and the impact of support schemes for public research spin-offs (Phan and Siegel 2006; Bozeman et al. 2015; Hayter and Link 2015; O'Kane et al. 2015). Thus, our findings are important for both, research as well as policy makers and PROs.

This paper is organized as follows. In the next section (Section 2) we describe the institutional setting of our empirical analysis, the Max Planck Society in Germany, and introduce the data. In Section 3 we discuss the empirical methodology used to identify the impact of support by the parent organization on the speed of commercialization of public research spin-offs and present the results of the econometric analysis. In Section 4 we summarize and discuss implications for universities and PROs, policy makers and for further research.

\section{Institutional Setting and Data}

\subsection{Academic entrepreneurship in the Max Planck Society}


We analyze the impact of support by the parent organization on the speed of commercialization of public research spin-off from the Max Planck Society (MPG) in Germany (Krabel and Mueller 2009; Krabel et al. 2012). The MPG consists of 83 institutes and research facilities worldwide, of which 78 are situated in Germany and employ ca. 9,000 researchers in natural sciences, life sciences, and humanities. Within the public science sector in Germany, the MPG is complementing universities by performing research in fields that universities are not able to embed in their research agenda, especially in cases of particularly new and innovative research that is uncertain and requires long-term commitment (i.e. structures and funding). Research excellence of the MPG is documented by 33 Nobel Prizes since 1911. According to Times Higher Education, the MPG is ranked number one of nonuniversity institutes in science and number 3 in technology after AT\&T and Argonne National Laboratory.

Though focused on basic research, the MPG has an institutionalized technology transfer office-Max Planck Innovation (MPI), a wholly owned subsidiary of the MPG. Max Planck Innovation was founded in 1970 with the main objective to facilitate the commercialization of research. Besides licensing ${ }^{2}$, the provision of professional support for MPG scientists who intend to create spin-off companies is a major objective of MPI (Max Planck Innovation 2015). Accordingly, MPI offers a wide spectrum of services for entrepreneurial scientists, ranging from general to quite specific and targeted support measures. MPI relies on its own experience, expertise and competences but also on a wide network of externals experts (external executive consultants; technical, design and product engineers), financiers, successful firm founders and experienced mentors and coaches who share their knowledge and experience about how to successfully start and run a business with the nascent entrepreneurs (Max Planck Innovation 2015). Assuming the role of a consultant, an intermediary and a 'sparring partner', MPI intend to help the nascent entrepreneurs (i) to detect technical and business flaws in the ideas already in the early phase and to make improvements, (ii) to help develop a sound business plan, and (iii) to establish contacts to suppliers, customers, financiers and other business partners (Max Planck Innovation 2015). MPI does not invest in spin-offs. As soon as a workable alpha prototype and a realistic and

\footnotetext{
${ }^{2}$ Max Planck Innovation, the technology transfer office of the Max Planck Society closes on average 150 license agreements a year, about half of them with companies abroad. The nature and extent of the licenses are as varied as the payment modalities. They range from upfront payments and sales-based royalties to additional milestone payments, e.g. in the case of drug development. Furthermore, according to self-reported records, Max Planck Innovation currently oversees more than 1,440 inventions and has shareholdings in 16 companies. Since 1979 Max Planck Innovation managed about 3,600 inventions and has closed more than 2,300 license agreements. The total revenues from Max Planck inventions currently amount to about 280 million Euro.
} 
economically sound business plan are developed and uncertainty associated with entrepreneurship is reduced, the MPI provides contacts to financiers such as banks, venture capitalists and business angels who take over (Max Planck Innovation 2015).

According to self-reported data, since 1990 Max Planck Innovation has spun off 79 companies that license inventions from the Max Planck Society and that belong to hightechnology industries such as life sciences, biotechnology, biochemistry and physical engineering (Max Planck Innovation 2015). ${ }^{3}$ The MPI coached nearly all of them in the founding process. Moreover, 52 companies were able to acquire venture capital, 7 went public, 22 were later subject of a merger/acquisition deals with/by existing companies in the field, and in 31 cases incumbent companies were shareholders in the new businesses.

\subsection{Data collection and sample}

Data on entrepreneurs at the Max Planck Society were collected by means of structured phone interviews with MPG scientists. We used a survey design in order to gather as many entrepreneurs as possible. Data collected by the technology transfer offices are typically found to severely underestimate entrepreneurial activity of scientists (Astebro and Bazzazian 2011 for an overview). In fact, while spin-offs that license inventions from Max Planck Society are reliably documented by Max Planck Innovation, the number of not-licensing-based spin-offs as well as the number of spin-offs not supported by Max Planck Innovation can not be recovered from the records (see Section 2.1 and Max Planck Innovation 2015).

We focused only on spin-offs from the 78 institutes of the Max Planck Society which are located in Germany. Before performing the survey, we contacted the executive directors of each of the 78 institutes to obtain permission to interview the scientists. The majority of directors (67 out of 78) permitted us to conduct the interviews and provided us with the necessary information to contact the scientists if it was not publicly available (on the internet). The targeted population for the survey consisted of 7,808 scientists working in 67 institutes (out of ca. 9,000 scientists in 78 institutes). The survey was conducted by a professional opinion research institute. Trained interviewers called every scientist in the targeted population by phone. Scientists who could not be contacted after three calls were dropped from the study. Participation in the survey was voluntary and scientists could skip any specific question as well as the entire survey. The feasibility and reliability of the survey questions

\footnotetext{
${ }^{3}$ A license based spin-offs is subject to a license, know-how or option agreement with Max Planck Innovation.
} 
were tested and improved during a pilot study. From the targeted population of 7,808 scientists, 2,604 (33.4\%) responded to the survey. To check the representativeness of the sample, we performed a non-response analysis considering characteristics that were publicly available (on the internet) such as field of research (biology, medical science, chemistry, physics, engineering, and humanities) and research position (doctoral student, post doctoral researcher, group leader, professor and director) and found that these 2,604 scientists fairly well represent the targeted population of 7,808.

We identified entrepreneurial scientists at the Max Planck Society by applying the definition of nascent entrepreneurship used in the Global Entrepreneurship Monitor and US-American Panel Study of Entrepreneurial Dynamics (Reynolds et al. 2004a, b). Accordingly, we classified scientists as nascent entrepreneurs if they just recently (within the last half year) started any activity associated with establishing an own business. These activities may include applying for public or private financing, seeking for venture capital, writing a business plan, looking for office space or forming the founding team. We focused on nascent entrepreneurs rather than on actual entrepreneurs because with starting an own business scientists typically leave the university or the PRO which makes data collection hardly possible (Astebro and Bazzazian 2011). Thus, by applying the nascent entrepreneurship concept we were able to identify entrepreneurs already in the process of starting a company but before leaving the current employer. In other words, the nascent entrepreneurship concept provides not only a more complete picture of the true entrepreneurial activities but also more realistic entrepreneurship rates (Parker and Belghitar 2006; Reynolds et al. 2004a, b; Astebro and Bazzazian 2011).

Information on support by the parent organization was obtained by asking the nascent entrepreneurs if they have received any support by the Max Planck Innovation since they started any activities towards establishing an own firm. Support by MPI could include business, technical or legal consulting, feasibility and proof of concept, coaching and mentoring, help in writing a business plan, help in searching and eventually providing business contacts as well as contacts to financiers (cf. Section 2.1).

To obtain information on the speed of commercialization (or the time to market), the scientists were asked to estimate the time they need to generate first revenues, since according to the definition of nascent entrepreneurship we adopted, the scientists in our sample have not yet started a business but are in the very early concept and seed phase (Reynolds et al. 2004a, b). For convenience, the scientists were given answers in four intervals: (i) in the next haft year, 
(ii) in half to one year, (iii) in one to three years, and (iv) in three years or later. We define the speed of commercialization as the time from starting any activity towards the establishment of an own firm to the date the scientists expect first revenues, and add half an year, since according to the nascent entrepreneurship definition, the scientists have started any activity towards establishing an own firm in the last half year. ${ }^{4}$

Overall, in our sample of 2,604 scientists, we find 50 (1.9\%) nascent entrepreneurs for whom we can analyze the impact of support by the parent organization on the speed of commercialization. This figure is at the lower bound of the rate of nascent entrepreneurs at universities and other PROs found in previous research (for an excellent overview see Astebro and Bazzazian 2011). However, previous entrepreneurship research also suggests that the entrepreneurship rates in Germany are relatively low in general (see various years of Global Report of the Global Entrepreneurship Monitor, GEM; Delmar and Davidsson 2000). ${ }^{5}$

The survey questions were particularly designed to analyze the entrepreneurial activities of scientists. Accordingly, besides the questions explicitly focusing on entrepreneurship, also a broad range of individual characteristics (work experience, skills and competences; risk aversion and psychological traits; social, family and demographic factors; etc.) and professional characteristics (position; type and innovativeness of research; scientific excellence; industry contacts; institutional characteristics; etc.) were collected which might be related to both the propensity to start a business and to the development and success of the ventures.

\section{The impact of support by the parent organization on the speed of commercialization of public research spin-offs}

\subsection{Descriptive evidence}

\footnotetext{
${ }^{4}$ We are aware that asking the scientists about the time of expected first revenues might introduce some imprecisions. However, targeting actual entrepreneurs from the Max Planck Society who have already started and generated first revenues comes typically at high costs of losing many of them, resulting in smaller number of observations. In section 3.1 we provide evidence that our approach unlikely leads to a large and systematic measurement error. In section 3.3 we apply instrumental variable approach that helps in case of selection bias and measurement error in the dependent variable.

${ }^{5} \mathrm{We}$ do not believe that the entrepreneurship rate we report in this study is downward biased because scientists conceal their entrepreneurial intentions/activities. First, at the beginning of the interviews, scientists were ensured that the survey is only for research purpose. Second, scientists at universities and PROs in Germany are legally allowed to run own businesses but also legally obligated to report such activities to their employers. Third, Max Planck Society actively supports those scientists who want to become entrepreneurs, however, scientists are absolutely free to ask (or not) for support.
} 
Our analysis of the impact of support by the parent organization on the speed of commercialization of public research spin-offs is based on 50 nascent entrepreneurs among the scientists in the Max Planck Society in Germany. The first noteworthy finding is that nearly the half (22) of the nascent entrepreneurs report support by Max Planck Innovation (Table 1). Overall, we find that ca. $46 \%$ of the entrepreneurs expect to generate first revenues within one and a half year after starting activities towards establishing an own firm. Further $24 \%$ of the nascent entrepreneurs in our sample expect to generate first revenues in one and a halt to three and a half years after starting first activities towards establishing an own firm, and $30 \%$ in three and a half years or later. These figures are in line with previous empirical findings (van Gelderen et al. 2006; Carter et al. 1996) ${ }^{6}$, suggesting that our measure for the time to first revenues is unlikely prone to a large and systematic measurement error as it is guessed by the respondents.

Table 1: $\quad$ Support by the parent organization and speed of commercialization of public research spin-offs — Descriptive evidence

\begin{tabular}{l|c|c}
\hline \hline $\begin{array}{l}\text { Time from starting any activity towards } \\
\text { establishing an own firm (nascent } \\
\text { entrepreneurship) to expected first revenues }\end{array}$ & $\begin{array}{c}\text { Supported by the } \\
\text { TTO } \\
(\mathrm{N}=22)\end{array}$ & $\begin{array}{c}\text { Not-supported by the } \\
\text { TTO } \\
(\mathrm{N}=28)\end{array}$ \\
\hline up to one year & $2(9.1 \%)$ & $2(7.1 \%)$ \\
\hline one year to one and a half years & $8(36.4 \%)$ & $11(39.3 \%)$ \\
\hline one and a half years to three and a haft years & $3(13.6 \%)$ & $9(32.1 \%)$ \\
\hline three and a half years and more & $9(40.9 \%)$ & $6(21.4 \%)$ \\
\hline \hline
\end{tabular}

A simple comparison of the supported and not-supported spin-offs does not provide clear-cut evidence as to whether support by the parent organization can speed up the commercialization process (Table 1). Comparably more supported (9.1\%) than not-supported (7.1\%) nascent entrepreneurs expect to generate first revenues within one year. However, slightly more notsupported (46.4\%) than supported (45.5\%) nascent entrepreneurs expect to generate first revenues within one and a half years after starting prepare an own firm. Similarly, more notsupported (78.5\%) than supported (59.1\%) entrepreneurs expect to generate first revenues within a period of maximum three and a half years. Finally, the share of supported entrepreneurs that expect to generate first revenues in three and a half years or later is with ca.

\footnotetext{
${ }^{6}$ van Gelderen et al. (2006) and Carter et al. (1996) do not relate the time to start up to support by the parent institution.
} 
$41 \%$ almost twice as large as the respective share among the not-supported (ca. 21\%).

However, drawing a final conclusion from Table 1 is hardly possible, as this simple comparison does not account for the possibility that supported and not-supported entrepreneurs might significantly differ with respect to characteristics that are related to both the likelihood to be supported and the time to market (cf. Table A1 in the Appendix).

\subsection{Interval regression}

In this section, we apply econometric techniques to more comprehensively assess the impact of support by the parent organization on the speed of commercialization of public research spin-offs. In fact, a simple comparison of the supported and not-supported spin-offs-as the one in Table 1 in Section 3.1, where we found no clear evidence that support by the parent organization speeds up the commercialization process - does not account for the possibility that supported and not-supported nascent entrepreneurs might differ regarding a number of characteristics that are related to both the fact that they are supported (or not) and the speed of commercialization. Hence, we apply multivariate regression techniques that allow us to assess the impact of support on the speed of commercialization conditional on a number of control variables such as individual characteristics (gender, age, industry experience) and characteristics of the spin-offs (business idea related to patent application, team founding, whether the business idea is based on research in life sciences/biotech, engineering, ICT or humanities). Additionally, we account for the availability of both a written business plan and external capital. ${ }^{7}$ We also account for regional heterogeneity in the conditions for entrepreneurship which might influence scientists' expectations by including the local GDP per capita (Fritsch and Falck 2007).

According to the nature of the dependent variable - the time from starting any activity towards establishing an own firm to the expected date of first revenues in four intervals: (i) up to one year, (ii) one year to one and a half years, (iii) one and a half years to three and a half years, and (iv) three and a half years and more-we apply interval regression techniques. Interval regression techniques are a generalization of the models fit by Tobit and are particularly developed for data where each observation represents interval data, left-censored

\footnotetext{
${ }^{7}$ In Section 3.4, we will relate the availability of a written business plan and external capital to support of MPI in order to analyze whether the support by the parent institution impacts on the speed of commercialization through these two particular channels.
} 
data, and right-censored data (Wooldridge 2013; Cameron and Triverdi 2010). The results are reported in Table 2. 
Table 2: $\quad$ Support by the parent organization and speed of commercialization of public research spin-offs — Results from interval regression

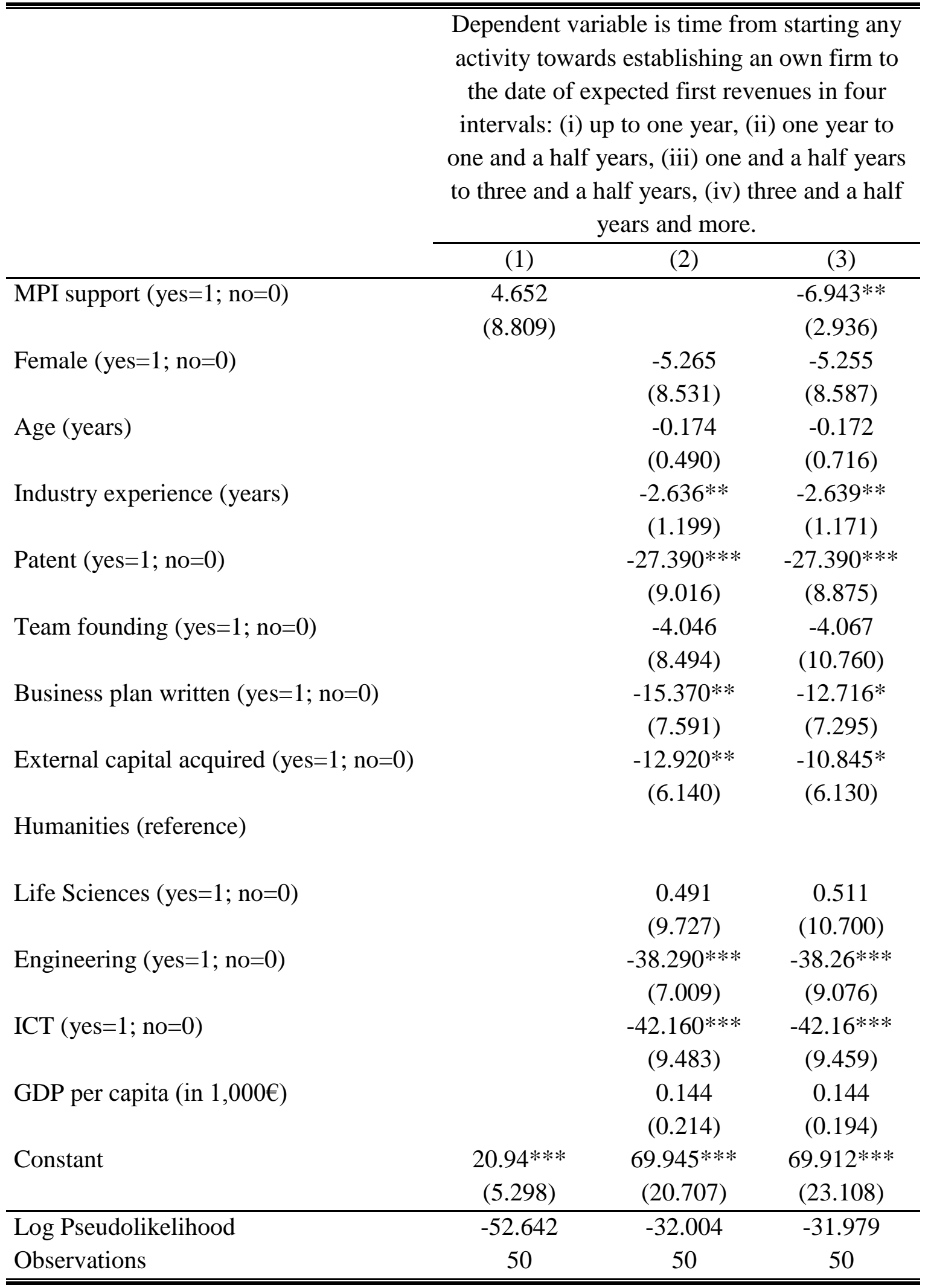

Note: Results from interval regression. Robust standard errors in parentheses. ${ }^{* * *}$ significant at $1 \%,{ }^{* *}$ significant at $5 \%, *$ significant at $10 \%$. 
The results of the analysis indicate that support by the parent organization is indeed associated with faster commercialization and that supported entrepreneurs expect to generate first revenues earlier than not-supported counterparts (Table 2). In specification (1) the coefficient of support by MPI is positive and insignificant, when no further characteristics of the entrepreneurs and the ventures are accounted for. This corresponds to the simple (univariate) comparison of supported and not-supported entrepreneurs presented in Table 1 in Section 3.1 which does not provide clear evidence whether support by the parent organization impacts on the speed of commercialization. In column (2) the results of a regression of the expected time to first revenues on only a set of entrepreneurs' individual characteristics and attributes of the spin-offs are presented. We find that entrepreneurs (i) whose business ideas are related to a patent, (ii) have industry experience, (iii) have a written business plan, and (iv) have been successful in acquiring external capital expect to generate first revenues earlier; age and gender seem to play no role. The local GDP per capita included to account for regional heterogeneity in the conditions for entrepreneurship which might influence scientists' expectations is statistically insignificant. In specification (3) we assess the impact of support by the parent organization conditional on the full set of characteristics of the entrepreneurs and their ventures. Once these sources of heterogeneity are accounted for, we find that, indeed, supported entrepreneurs expect to generate first revenues earlier than their notsupported counterparts; the coefficient of MPI support is negative and significant.

\subsection{Instrumental variable estimation}

In this section we apply an instrumental variable approach to even more rigorously assess the impact of support by the parent organization on the speed of commercialization of public research spin-offs. In the previous Section 3.2 we use multivariate regression techniques to assess the importance of support by the parent organization conditional on a number of characteristics of the entrepreneurs and the spin-offs. However, we can not ex ante rule out that there are further characteristics that we can not observe and can not account for, and that are, however, related the likelihood that spin-offs get support as well as to their ability to generate first revenues. In such a case, the results of a multivariate regression analysis in the previous Section 3.2 would be biased. For instance, we would expect a downward bias (lower impact of the support by the parent organization, or in other words underestimation) if entrepreneurs that would have otherwise needed more time to generate first revenues report relatively more often support. On the contrary, we would expect an upward bias (stronger 
impact of the support by the parent organization, or in other words overestimation) if entrepreneurs that would have anyways needed less time to generate first revenues report relatively more often support. As the process behind getting support or not is ex ante not known, magnitude and direction of the potential bias are also not clear. ${ }^{8}$

As an instrument we use the travel time between the working place (i.e. the institute) of each nascent entrepreneur and Max Planck Innovation in Munich. Specifically, we calculate the travel time (in minutes) between each institute and MPI in Munich for three travel modes-by car, by train, and by plane - and use the shortest one. The instrument relies on the fact that support for the spin-offs requires close and frequent interactions between founder and the supporting organization, so that scientists located closer to Max Planck Innovation are c.p. more likely to make use of it regardless their type and abilities. Thus, the instrument is arguably not related to the characteristics of the nascent entrepreneurs or the ventures. Moreover, the instrument is hardly related to characteristics of the local environment that might also influence the speed of commercialization. The reason is that the different Max Planck institutes are located in exactly those places that (are thought to) provide the best possible supportive environment for the scientists in a specific field of research, in particular professional and scientific networks (e.g. near distinguished university or an industrial cluster etc.) whereas Max Planck Innovation is located in Munich only because Munich is where the headquarter of the society is. ${ }^{9}$

\footnotetext{
${ }^{8}$ IV approach can also help in cases where the dependent variable is measured with error (Angrist and Krueger 1991; Ashenfelter and Krueger 1994; Bound et al. 1994), as in our case, where the time to first revenues is guessed by the respondents. Random measurement error in the dependent variable does not bias the slope coefficient; it does lead to larger standard errors. Assuming this scenario (likelier than systematic measurement error, if at all), it is encouraging that we find statistically significant coefficients for the variable of main interest. However, even when the measurement error in the dependent variable is correlated with the true dependent variable or with the RHS variables, we can still get consistent estimates by using instrumental variables as long as the instrument(s) are only correlated with true RHS variables but not with the measurement error. That is, the instruments most likely to be helpful in this case are the types of instruments we would be using anyway for other reasons (say to cure selection bias).

${ }^{9}$ There is no reason to believe that our instrument captures the effect possible positive/negative externalities of being located near/far from the prosperous Munich which might influence scientists' expectations. Although prosperous, Munich does not provide the best possible conditions for scientists and firms in each and every field, because - at regional level — entrepreneurship requires a rather complex and multidimensional ecosystem. For instance, the Max Planck Institute for Marine Microbiology is located in Bremen at the North Sea. Similarly, the institutes focused on medical research - the Max Planck Institute for Biophysical Chemistry, the Max Planck Institute for Experimental Medicine and the Max Planck Institute for Medical Research - are located in Goettingen and Heidelberg that host universities with medical departments among the strongest in Germany. Moreover, though financial institutions - particularly VCs - are concentrated in few major centers, one of which is Munich, there is no evidence whatsoever for a spatial financial gap (Fritsch and Schilder 2008, 2012). Not least, remaining confounding effects should be captured by the local GDP per capita included to account for regional heterogeneity in the conditions for entrepreneurship (Fritsch and Falck 2007).
} 
Table 3: $\quad$ Support by the parent organization and speed of commercialization of public research spin-offs - Results from instrumental variable approach

\begin{tabular}{|c|c|c|}
\hline & $\begin{array}{c}\text { Dependent } \\
\text { variable is MPI } \\
\text { support } \\
\text { (yes }=1 ; \text { no }=0 \text { ) }\end{array}$ & $\begin{array}{l}\text { Dependent variable is time from } \\
\text { starting any activity towards } \\
\text { establishing an own firm to the date } \\
\text { of expected first revenues in four } \\
\text { intervals: (i) up to one year, (ii) one } \\
\text { year to one and a half years, (iii) } \\
\text { one and a half years to three and a } \\
\text { half years, (iv) three and a half years } \\
\text { and more. }\end{array}$ \\
\hline & (logit) & (interval regression) \\
\hline MPI support (yes $=1 ;$ no $=0)$ & & $\begin{array}{c}-8.322 * * \\
(3.712)\end{array}$ \\
\hline Travel time (minutes) & $\begin{array}{c}-0.061 * * \\
(0.028)\end{array}$ & \\
\hline Female $($ yes $=1 ;$ no $=0)$ & $\begin{array}{c}4.447 \\
(5.860)\end{array}$ & $\begin{array}{l}-9.350 \\
(7.991)\end{array}$ \\
\hline Age (years) & $\begin{array}{l}0.886^{*} \\
(0.511)\end{array}$ & $\begin{array}{c}0.006 \\
(0.454)\end{array}$ \\
\hline Industry experience (years) & $\begin{array}{c}-0.629 * * \\
(0.267)\end{array}$ & $\begin{array}{c}-2.508 * * \\
(1.053)\end{array}$ \\
\hline Patent $($ yes $=1 ;$ no $=0)$ & $\begin{array}{l}-0.534 \\
(2.976)\end{array}$ & $\begin{array}{c}-30.137 * * * \\
(9.221)\end{array}$ \\
\hline Team founding $($ yes $=1 ;$ no $=0)$ & $\begin{array}{l}-0.199 \\
(2.218)\end{array}$ & $\begin{array}{c}9.982 \\
(7.229)\end{array}$ \\
\hline Business plan written $($ yes $=1 ;$ no $=0$ ) & $\begin{array}{l}4.177 * * \\
(1.738)\end{array}$ & $\begin{array}{c}-21.252 * * * \\
(7.359)\end{array}$ \\
\hline External capital acquired $($ yes $=1 ;$ no $=0$ ) & $\begin{array}{l}9.649 * \\
(5.762)\end{array}$ & $\begin{array}{c}16.160 \\
(12.596)\end{array}$ \\
\hline \multicolumn{3}{|l|}{ Humanities (reference) } \\
\hline Life Sciences $($ yes $=1 ;$ no $=0$ ) & $\begin{array}{l}-0.752 \\
(2.022)\end{array}$ & $\begin{array}{c}-3.004 \\
(10.549)\end{array}$ \\
\hline Engineering $($ yes $=1 ;$ no=0 $)$ & $\begin{array}{l}1.528 \\
(2.977)\end{array}$ & $\begin{array}{c}-38.942 * * * \\
(6.023)\end{array}$ \\
\hline ICT $($ yes $=1 ;$ no=0) & $\begin{array}{l}-4.913 \\
(3.135)\end{array}$ & $\begin{array}{c}-44.815^{* * *} \\
(8.095)\end{array}$ \\
\hline GDP per capita (in $1,000 €$ ) & $\begin{array}{c}0.027 \\
(0.073)\end{array}$ & $\begin{array}{l}-0.454 \\
(0.293)\end{array}$ \\
\hline Constant & $\begin{array}{l}-29.983 \\
(18.030)\end{array}$ & $\begin{array}{c}101.833 * * * \\
(24.412)\end{array}$ \\
\hline Observations & 50 & 50 \\
\hline
\end{tabular}

Note: The first column reports the results of a logit regression of getting support by Max Planck Innovation 
(MPI) on the travel time between nascent entrepreneurs' work place (i.e., institute) and MPI in Munich. The second column presents the results of an interval regression of the time to first revenues on the predicted values of getting support from MPI from the first stage; that is, from the logit regression in the first column. Robust standard errors in parentheses. $* * *$ significant at $1 \%, * *$ significant at $5 \%, *$ significant at $10 \%$.

The results from the IV approach support a causal interpretation of the findings that support by the parent organization can speed up the process of commercialization and help public research spin-off quicker generate first revenues (Table 3). In the first column we report the results of a logit regression with support by the parent organization (yes $=1$; no $=0$ ) as a dependent variable and the travel time between entrepreneurs' work place and Max Planck Innovation in Munich as independent. In line with our argument, the coefficient on the travel time is significant and negative, indicating that the entrepreneurs located further from Munich are c.p. less likely to report support by Max Planck Innovation. ${ }^{10}$ In column two of Table 3 we report the results of an interval regression of the time to expected first revenues on the predicted values of support by the parent organization from the first stage in column one. ${ }^{11}$ The estimated coefficient on support by the parent organization is significant and negative, indicating that supported entrepreneurs expect to generate first revenues earlier than notsupported counterparts. Compared to the results from the simple interval regression in Table 2 in Section 3.2, the coefficient on support by MPI from the IV estimation is larger in magnitude. As mentioned above, the simple interval regression would underestimate the true impact of support if entrepreneurs that would otherwise have needed more time to generate first revenues are comparably more often among the supported and this is not properly accounted for. That this might indeed be the case is also supported by Table 1 where we find among the supported entrepreneurs comparably more individuals that expect to generate first revenues in three and a half years or later.

\subsection{Channels of impact}

\footnotetext{
${ }^{10}$ The average marginal effect of the travel time is ca. -0.002 suggesting that 50 minutes travel time reduces the likelihood of reporting support by Max Planck Innovation by $10 \%$.

${ }^{11}$ As there is no straightforward way to account for the fact that the values of MPI support in the second column are the predicted values from the logit regression in the first column (standard errors from the logit regression are not normal as in the linear model), the estimates should be interpreted with caution. However, given the kind of data we have - binary variable for support by the TTO and interval data for the time of commercialization-we prefer this approach over a 2SLS since the precision of estimation of a linear model on such data depends crucially on the number of observations.
} 
In this section we analyze two specific channels through which support by the parent organization can speed up the process of commercialization and help spin-offs quicker generate first revenues. In particular, as mentioned above, self-declared aim of Max Planck Innovation is to support nascent entrepreneurs in developing a sound business plan and in acquiring external capital. To achieve this goal, Max Planck Innovation offers help by internal and external executive consultants, by technical, design and product engineers or other experts, conducts feasibility studies, proofs of the concept, market research, etc. Indeed, in our previous analysis of the determinants of the speed of commercialization and the time to first revenues in Table 2 in Section 3.2, we find that as soon as we introduce support by Max Planck Innovation, the estimated coefficients for having a written business plan and for the availability of external capital decrease in magnitude and become less significant. This provides some indication that the effect of support by Max Planck Innovation on the speed of commercialization unfolds (partially) through help in writing a business plan and acquiring external capital.

To explicitly assess the impact of support by MPI on the development of a business plan and on the acquisition of external capital, we apply seemingly unrelated bivariate probit regression techniques, since both, the outcome variables (availability of business plan and external capital) and the potentially endogenous regressor (support by MPI) are binary (Greene 2003; Fairlie 2006). In fact, simply regressing the availability of business plan and external capital on support by MPI might yield biased results, if there are unobserved characteristics of the entrepreneurs and their ventures that are related to the likelihood to report support by Max Planck Innovation on the one hand and the availability of business plan and external capital on the other. Moreover, there might reverse causality if entrepreneurs with business plan and external capital are more likely to ask for and get support by MPI. In the bivariate probit two equations are simultaneously estimated: a standard equation where the outcome (in our case business plan and external capital respectively) is regressed on the potentially endogenous variable (support by MPI), and another equation in which the potentially endogenous variable itself is regressed on a number variables that might be included in the first equation or not (i.e., exogenous). Similar to the IV analysis in Section 3.3, we use the travel time between scientists' work place (i.e. the respective institute) and Max Planck Innovation in Munich as exclusion restriction to exogenously explain the likelihood of reporting support by Max Planck Innovation. The results are reported in Table 4. 
Table 4: Channels of impact of support by the parent organization on the speed of commercialization of public research spin-offs - Business plan and external capital

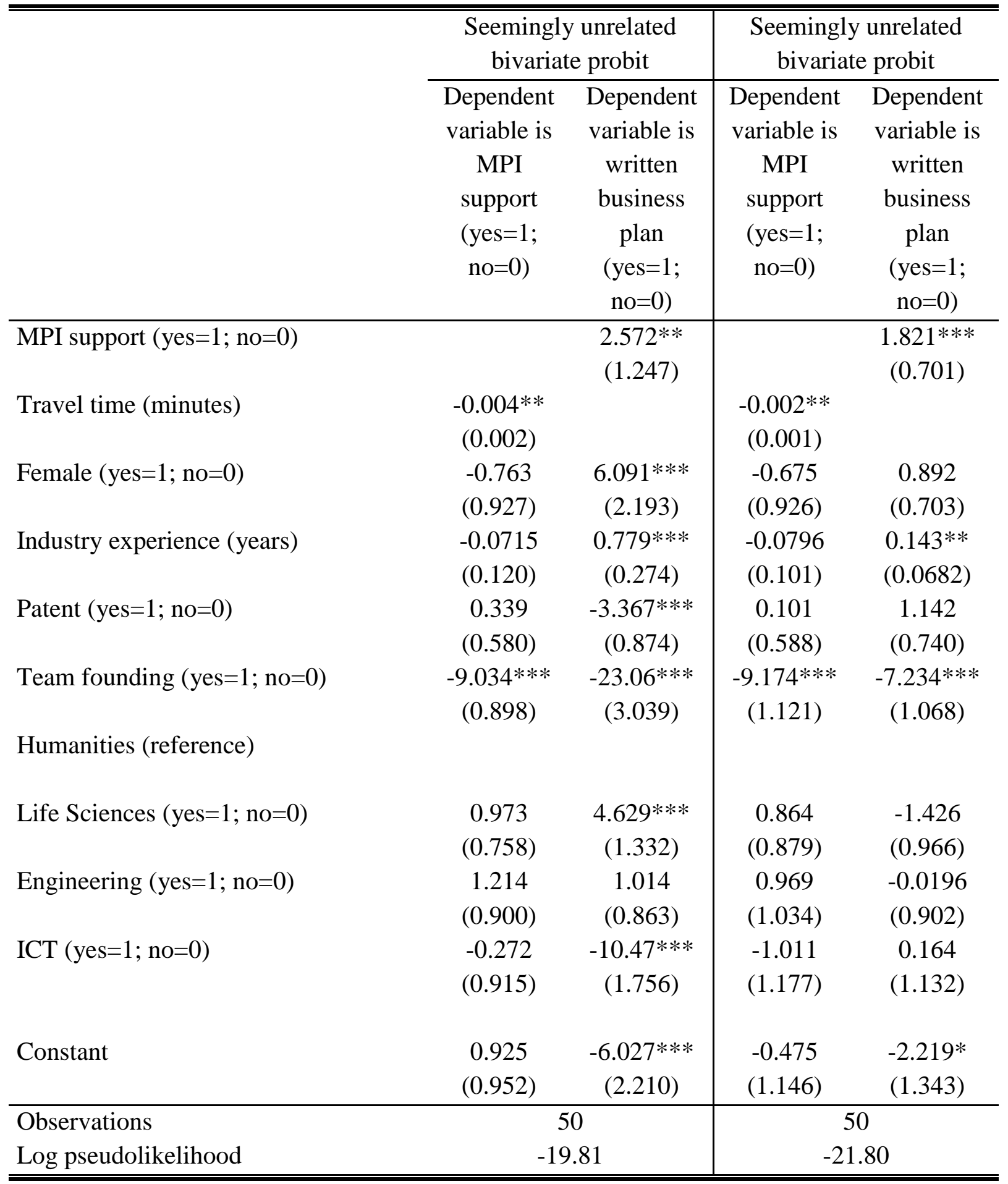

Note: Results of seemingly unrelated bivariate probit regressions. Robust standard errors in parentheses. ${ }^{* * *}$ significant at $1 \%, * *$ significant at $5 \%, *$ significant at $10 \%$.

The results of the bivariate probit analysis in Table 4 confirm that entrepreneurs supported by the parent organization are c.p. more likely to have a written business plan and to have been 
successful in acquiring external capital; the estimated coefficient of MPI support is in both cases positive and statistically significant. This indicates that support by the parent organization speeds up the process of commercialization and helps spin-offs generate first revenues quicker by, among other channels, helping scientist to quicker develop a sound business plan and to acquire external capital.

\section{Summary and discussion}

In this paper we empirically analyze whether support by the parent organization in the early nascent and seed phase can speed up the commercialization process and help spin-offs from public research organizations quicker generate first revenues. While the vast majority of the existing literature on academic entrepreneurship focuses on the determinants of higher entrepreneurial incidence at PROs, comparably less is known whether and through which channels does support by the parent organization impact on the development of the spin-offs. Assessing the impact of support by the parent organization on the speed of commercialization and the time to market is important because the ability to quickly enter the market with a given product, to generate revenues and thereby to break even is positively associated with subsequent survival, development and performance (McEvily et al. 2004; Meyer 1993; Rosenthal 1992; Wheelwright and Clark 1996; Kessler and Chakrabarti 1996; McGrath 1999). In fact, firms that succeed in speeding products faster to the market can obtain firstmover advantage, higher profitability and market shares (Droege et al. 2005; Takeuchi and Nonaka 1986; Eisenhardt and Martin 2000).

The analysis is performed at the example of spin-offs from the Max Planck Society in Germany, one of the worldwide most distinguished public research organizations. We interview nascent entrepreneurs at the Max Planck Society and proxy the speed of commercialization by the time from starting any activity towards the establishment of an own firm to the date of expected first revenues. To assess the impact of support by the parent organization we apply multivariate regression techniques as well as instrumental variable approach that helps avoid potential biases which could arise (i) if there are characteristics of the entrepreneurs and their ventures that are simultaneously related to the likelihood that spinoffs get support and to their ability to generate first revenues, and which are not accounted for in the multivariate regression, and (ii) due to measurement error in the time to first revenues that is estimated by the nascent entrepreneurs. Our results support a causal interpretation of 
the findings that support by the parent organization can speed up the process of commercialization and help public research spin-off quicker generate first revenues.

Moreover, we investigate two particular impact channels and find that support by the parent organization unfolds its impact by helping entrepreneurs in developing a business plan as well as in acquisition of external capital.

The findings of this study complement the literature on academic entrepreneurship in general and add to the understanding on whether and how exactly support by the parent organization impact on the development of the ventures in particular. However, our findings contribute also to the literature that aims at evaluating the effectiveness and the impact of public support schemes for public research spin-offs (Phan and Siegel 2006; Bozeman et al. 2015; Hayter and Link 2015; O’Kane et al. 2015).

Though our econometric analysis allows causal interpretation of the findings that support by the parent organization reduces the time from starting activities towards the establishment of an own firm to the date of expected first revenues, and is, thereby, relevant for both research and practitioners, generalizing from our study and deriving concrete and final policy recommendation is not an easy task. First, in order not to loose too many scientists that leave academia to start a firm, we apply the nascent entrepreneurship concept and focus on the time to expected first revenues. Our figures are in line with previous empirical findings (van Gelderen et al. 2006; Carter et al. 1996), suggesting that our measure for the time to market is unlikely subject to a large and systematic measurement error. Moreover, in order to be on the safe side, we additionally apply instrumental variables techniques that help, among other things, cope with potential measurement error. However, further research that solves this issue would be appreciated. Second, and more important, generalizing and deriving implications for policy and public research organizations might be difficult since our results are based on a sample from a single organization, the Max Planck Society. Focusing on a single organization has major advantages as it reduces unobserved heterogeneity (in particular treatment heterogeneity) and therefore allows draw robust inference. However, for policy it is crucial to know whether and how important the particular institutional and organizational setting is and to which extent findings from a single organization can be transferred to other institutional and/or organizational environments.

Overall, deriving final policy recommendation requires answering the question about the optimal design of support measures for spin-off at PROs. For instance, there are lots of possibilities for the parent organizations to come to the aid of scientists that want to become 
entrepreneurs since these often lack skills and competences that are important for successful entrepreneurship such as entrepreneurial and industry experience, business contacts, knowledge about markets, competition, management, human resources, finance, ect. We illuminated two specific channels through which support by the TTO can unfold its effectshelp in business plan and in acquiring external capital-, however, futures research is required to fully open the black box of university TTO support. Moreover, it is also important to know whether support by the parent organization impacts on further characteristics of the spin-offs which define their success (e.g., help in acquiring the appropriate human capital, business contact, legal issues, initial size, etc.). Furthermore, it is important to know whether and how TTOs and other institutions within the same organization interact and complement each other (e.g. cultural differences between scientists and TTO staff). Also understanding interactions and complementarity between different support measures and whether there is an optimal set of such is important for maximizing the impact. Similarly, for the optimal design of spin-offs support measures is required to uncover whether and which characteristics of the institutional and organizational characteristics influence their effectiveness and are important for the success of the measures, that is of the spin-offs. As mentioned above (see Introduction), size, qualification, experience of the TTOs are found associated with higher entrepreneurial incidence at the respective institutions. However, it is not known whether these same characteristics also help speed up the process of commercialization and contribute the long term development of the spin-offs.

Not least, a policy recommendation requires evaluating the efficiency of support schemes at universities and other public research organizations. Our study provides some information about the question of when it is effective to support firms. We find that support by the parent institutions in the very early, pre-start stages of the development of the new businesses can play a role. The results indicate that support by the parent organizations helps spin-offs develop a sound business plan and acquire external capital, which implies stronger incentives for private financiers due to higher returns, at least in the short run. However, it is an open question whether support in the early stage is generally more efficient than support in later stages. More importantly, for policy is important to know the causal effect of support by the parent institution on the performance of the spin-offs in the long run. Though there is evidence that being early on the market and quickly generating first revenues can generate short run advantages, the effects in the long run are likely depending on the type of and degree of innovation, the stage in the product life cycle, and the intensity and type of competition (Langerak and Hultink 2005; Suarez and Lanzolla 2005; Robinson et al 1994). 
Moreover, it is important to know along which dimension the effects unfold (growth,

productivity, profitability, survival) and whether and how persistent these are. We believe that all these are valuable avenues for further research. 


\section{References}

Angrist, J. D., Krueger, A. B. (1991). Does compulsory schooling attendance affect schooling and earnings? Quarterly Journal of Economics, 106, 979-1014.

Ashenfelter, O., Krueger, A. B. (1994). Estimates of the economic return to schooling from a new sample of twins. American Economic Review, 84, 1157-1173.

Astebro, T., Bazzazian, N. (2011). Universities, entrepreneurship, and local economic development. In M. Fritsch (Ed.), Handbook of research on entrepreneurship and regional development. Cheltenham, UK: Edward Elgar.

Astebro, T., Bazzazian, N., Braguinsky, S. (2012). Startups by recent university graduates and their faculty: Implications for university entrepreneurship policy. Research Policy, 41, 663677.

Bound, J., Brown, C., Duncan G. J., Rodgers, W. L. (1994). Evidence on the validity of crosssectional and longitudinal labor market data. Journal of Labor Economics, 12, 345-368.

Brennan, M. C., Wall, A. P., McGowan, P. (2005). Academic entrepreneurship: Assessing preferences in nascent entrepreneurs. Journal of Small Business and Enterprise Development, $12,307-322$.

Brennan, M. C., McGowan, P. (2006). Academic entrepreneurship: An exploratory case study. International Journal of Entrepreneurial Behavior \& Research, 12, 144-164.

Boeker, W. (1989). Strategic change: The effects of founding and history. Academy of Management Journal, 32, 489-515.

Bozeman, B., Rimes, H., Youtie, J. (2015). The evolving state-of-the-art in technology transfer research: Revisiting the contingent effectiveness model. Research Policy, 44, 34-49.

Cameron, A.C., Trivedi, P.K. (2010). Microeconometrics Using Stata. Rev. ed. College Station, TX: Stata Press.

Carter, N.M., Gartner, W.B., Reynolds, P.D. (1996). Exploring start-up event sequences. Journal of Business Venturing, 11, 151-166.

Clarysse, B., Tartari, V., Salter, A. (2011). The impact of entrepreneurial capacity, experience and organizational support on academic entrepreneurship. Research Policy, 40, 1084-1093. 
Cooper, A.C., Gimeno-Gascon, F.J., Woo, C.Y. (1994). Initial human and financial capital as predictors of new venture performance. Journal of Business Venturing, 9, 371-395.

Dahlqvist, J., Davidsson, P., Wiklund, J. (2000). Initial conditions as predictors of new venture performance: A replication and extension of the Cooper et al. study. Enterprise Innovation Management Studies, 1, 1-17.

Delmar, F., Davidsson, P. (2000). Where do they come from? Prevalence and characteristics of nascent entrepreneurs. Entrepreneurship and Regional Development, 12, 1-23.

Di Gregorio, D., Shane, S. (2003). Why do some universities generate more start-ups than others? Research Policy, 32, 209-227.

Droege, C., Jayaram, J., Vickery, S.K. (2000). The ability to minimize the timing of new product development and introduction: An examination of antecedent factors in the North American automobile supplier industry. Journal of Product Innovation Management, 17, 2440.

Eisenhardt, K., Martin, J. (2000). Dynamic capabilities: What are they? Strategic Management Journal, 21, 1105-1121.

Ensley, M.D., Hmieleski, K.A. (2005). A comparative study of new venture top management team composition, dynamics and performance between university-based and independent start- ups. Research Policy, 34, 1091-1105.

Etzkowitz, H. (2004). The evolution of the entrepreneurial university. International Journal of Technology and Globalisation, 1, 64-77.

Fairlie, R. (2006). The personal computer and entrepreneurship. Management Science, 52, 187-203.

Fini, R., Grimaldi, R., Sobrero, M. (2009). Factors fostering academics to start up new ventures: An assessment of Italian founders' incentives. Journal of Technology Transfer, 34, 380-402.

Fritsch, M., Falck, O. (2007). New business formation by industry over space and time: A multidimensional analysis. Regional Studies, 41, 157-172.

Fritsch, M., Schilder, D. (2008). Does venture capital investment really require spatial proximity? An empirical investigation. Environment and Planning A, 40, 2114-2131. 
Fritsch, M., Schilder, D. (2012). The regional supply of venture capital: Can syndication overcome bottlenecks? Economic Geography, 88, 59-76.

Greene, W.H. (2003). Econometric analysis, 5th ed. Upper Saddle River, NJ: Prentice Hall.

Grimaldi, R., Kenney, M., Siegel, D. S., Wright, M. (2011). 30 years after Bayh-Dole: Reassessing academic entrepreneurship. Research Policy, 40, 1045-1057.

Hayter, C.S., Link, A.N. (2015). On the economic impact of university proof of concept centers. Journal of Technology Transfer, 40, 178-183.

Holley, A. C., Watson, J. (2011). Mapping the entrepreneurial mindset of life science academics. International Council for Small Business (ICSB) World Conference Proceedings Washington, 1-24.

Kessler, E., Chakrabarti, A. (1996). Innovation speed: A conceptual model of context, antecedents and outcomes. Academy of Management Review, 21, 1143-1191.

Koster, S. (2006). Whose child? How existing firms foster new firm formation: Individual start-ups, spin-outs and spin-offs. Dissertation. University of Groningen, Faculty of Spatial Sciences: Groningen.

Krabel, S., Mueller, P. (2009). What drives scientists to start their own company?: An empirical investigation of Max Planck Society scientists. Research Policy, 38, 947-956.

Krabel, S.; Siegel, D. S.; Slavtchev, V. (2012). The Internationalization of science and its influence on academic entrepreneurship. Journal of Technology Transfer, 37, 192-212.

Langerak, F., Hultink, E.J. (2005). The impact of product innovativeness on the link between development speed and new product profitability. Journal of Product Innovation Management, 23, 203-214.

Lerner, J. (2005). The university and the start-up: Lessons from the past two decades. Journal of Technology Transfer, 30, 49-56.

Lieberman, M.B., Montgomery, D.B. (1998). First-mover advantages. Strategic Management Journal, 9, 41-58.

Lindholm Dahlstrand, A. (1997). Entrepreneurial spin-off enterprises in Goeteborg, Sweden. European Planning Studies, 5, 659-673. 
Link, A.N., Siegel, D.S. (2005). University-based technology initiatives: Quantitative and qualitative evidence. Research Policy, 34, 253-257.

Lockett, A., Siegel, D., Wright, M., Ensley, M.D. (2005). The creation of spin-off firms at public research institutions: Managerial and policy implications. Research Policy, 34, 981993.

Lockett, A., Wright, M. (2005). Resources, capabilities, risk capital and the creation of university spin-out companies. Research Policy, 34, 1043-1057.

Markman,G.D., Gianiodis, P.T., Phan, P.H., Balkin, D.B. (2005). Innovation speed: Transferring university technology to market. Research Policy, 34, 1058-1075.

Max Planck Innovation (2015). http://www.max-planck-innovation.de/en/ (accessed 31.01.2015)

McEvily, S., Eisenhardt, K., Prescott, J. (2004). The global acquisition, leverage, and protection of technological competencies. Strategic Management Journal, 25, 713-722.

McGrath, R. (1999). Falling forward: Real options reasoning and entrepreneurial failure. Academy of Management Review, 24, 13-30.

Meyer, C. (1993). Fast cycle time: How to align purpose, strategy, and structure for speed. New York: Free Press.

Moray, N., Clarysse, B. (2005). Institutional change and resource endowments to sciencebased entrepreneurial firms. Research Policy, 34, 1010-1027.

Mowery, D., Nelson, R., Sampat, B., Ziedonis, A. (2004). Ivory tower and industrial innovation: University-industry technology transfer before and after the Bayh-Dole Act in the United States. Stanford, CA: Stanford University Press.

Mustar, P., Wright, M. (2010). Convergence or path dependency in policies to foster the creation of university spin-off firms? A comparison of France and the United Kingdom. Journal of Technology Transfer, 35, 42-65.

Mustar, P., Wright, M., Clarysse, B. (2008). University spin-off firms: Lessons from ten years of experience in Europe. Science and Public Policy, 35, 67-80.

O'Kane, C., Mangematin, V., Geoghegan, W., Fitzgerald, C. (2015). University technology transfer offices: The search for identity to build legitimacy. Research Policy, 44, 421-437. 
O’Shea, R.P., Allen, T.J., Chevalier, A., Roche, F. (2005). Entrepreneurial orientation, technology transfer and spinoff performance of U.S. universities. Research Policy, 34, 9941009.

O’Shea, R.P., Allen, T.J., O’Gorman, C., Roche, F. (2004). Universities and technology transfer: A review of academic entrepreneurship literature. Irish Journal of Management, 25, 11-29.

Parker, S.C., Belghitar, Y. (2007). What happens to nascent entrepreneurs? An econometric analysis of the PSED, Small Business Economics, 27, 81-101.

Phan, P., Siegel, D.S. (2006). The effectiveness of university technology transfer. Foundations and Trends in Entrepreneurship, 2, 77-144.

Powers, J., McDougall, P. (2005). University start-up formation and technology licensing with firms that go public: A resource based view of academic entrepreneurship. Journal of Business Venturing, 20, 291-311.

Reynolds, P.D., Bygrave, W.D., Autio, E. (2004a). Global Entrepreneurship Monitor. 2003 Executive Report. Kansas City: Ewing Marion Kauffman Foundation.

Reynolds, P.D., Carter, N.M., Gartner, W.B., Greene, P.G. (2004b). The prevalence of nascent entrepreneurs in the United States: Evidence from the Panel Study of Entrepreneurial Dynamics, Small Business Economics, 23, 263-284.

Robinson, W.T., Kalyanaram, G., Urban, G.L. (1994). First mover advantages from pioneering new markets: A survey of empirical evidence. Review of Industrial Organization, 9, 1-23.

Rosenthal, S. (1992). Effective product design and development: How to cut lead time and increase customer satisfaction. Homewood, IL: Business One Irwin.

Rothaermel, F.T., Agung, S., Jiang, L. (2007). University entrepreneurship: A taxonomy of the literature. Industrial and Corporate Change, 16, 691-791.

Shane, S. (2004). Academic entrepreneurship: University spinoffs and wealth creation. Aldershot, UK: Edward Elgar.

Shane, S. (2008). Illusions of entrepreneurship: The costly myths that entrepreneurs, investors, and policy makers live by. New Haven, CT: Yale University Press. 
Siegel, D.S., Wright, M., Lockett, A. (2007). The rise of entrepreneurial activity at universities: Organizational and societal implications. Industrial and Corporate Change, 16, 489-504.

Stephan, A. (2014). Are public research spin-offs more innovative? Small Business Economics, 43, 353-368.

Takeuchi, H., Nonaka, I. (1986). The new product development game. Harvard Business Review, 64, 137-146.

van Gelderen, M., Thurik, R., Bosma, N. (2006). Success and risk factors in the pre-startup phase. Small Business Economics, 26, 319-335.

Vohora, A., Wright, M., Lockett, A. (2004). Critical junctures in the development of university high-tech spinout companies. Research Policy, 33, 147-175.

Walter, A., Auer, M., Ritter, T. (2006). The impact of network capabilities and entrepreneurial orientation on university spin-off performance. Journal of Business Venturing, 21, 541-567.

Wheelwright, S., Clark, K. (1996). Accelerating the design-build-test cycle for effective product development. In Burgelman, R.A., Maidique, M.A., Wheelright, S.C. (Eds.), Strategic Management of Technology and Innovation (pp. 859-868). Chicago: Irwin.

Wooldridge, J.M. (2013). Introductory Econometrics: A Modern Approach. 5th ed. Mason, $\mathrm{OH}$ : South-Western.

Wright, M., Clarysse, B., Mustar, P., Lockett, A. (2007). Academic entrepreneurship in Europe. Cheltenham: Edward Elgar.

Wright, M., Lockett, A., Clarysse, B., Binks, M. (2006). University spin-out companies and venture capital. Research Policy, 35, 481-501.

Zhang, J. (2009). The performance of university spin- offs: An exploratory analysis using venture capital data. Journal of Technology Transfer, 34, 255-286. 


\section{Appendix}

Table A1: Descriptive statistics

\begin{tabular}{l|c|c}
\hline \hline & Non-supported & Supported \\
\hline Life Science (no=0; yes=1) & 0.24 & 0.50 \\
Engineering (no=0; yes=1) & 0.24 & 0.36 \\
ICT (no=0; yes=1) & 0.41 & 0.07 \\
Humanities (0; yes=1) & 0.12 & 0.07 \\
Female (no=0; yes=1) & 0.24 & 0.29 \\
Age (years) & 32.9 & 36.7 \\
Business idea related to a patent (no=0; yes=1) & 0.35 & 0.50 \\
Industry experience (years) & 2.2 & 1.9 \\
Team founding (no=0; yes=1) & 0.13 & 0.00 \\
Business plan written no= $(0 ;$ yes=1) & 0.29 & 0.64 \\
External capital acquired (no=0; yes=1) & 0.17 & 0.21 \\
\hline \hline
\end{tabular}

Note: Means. 
